\title{
Çocuklarda Baş-Boyun Bölgesi Haricinde Oluşan Tümörlerin Tedavisinde Kullanılan Antineoplastik Ajanların Diş Gelişimi Üzerindeki Etkileri
} The Effects of the Antineoplastic Agents Used for the Treatment of Non-Head and Neck Tumors on the Teeth Development in Children

Ali Sinan Horasan

Girne Üniversitesi Diș Hekimliği Fakültesi, Ağız-Diş ve Çene Radyolojisi Anabilim Dalı, Girne, KKTC

Özet: $\mathrm{Bu}$ çalışmanın amacı; çocukluk çağı tümörlerinde baş-boyun bölgesi haricinde oluşan neoplazmların tedavisinde kullanılan antineoplastik ajanların diș ve çene gelișimine etkisini araștırmaktır. Bu çalısma, tümör lokalizasyonu baș-boyun bölgesi dıșında olușan, yaşları 3 ve 14 arasında değişen, kemoterapi uygulanan ve başka bir sistemik hastalığı olmayan 30 hasta üzerinde yapılmıştır. Bu hastalardan tedavinin başlangıcında, tedavinin sonunda ve tedavi bitiminden 12 ay sonra periapikal ve panoramik radyografiler çekilerek diş ve diş köklerinin uygulanan kemoterapötik ajanlardan etkilenip etkilenmediği incelenmiștir. Hastalarda sürmede gecikme, kök agenezi, kökte incelme, apeksifikasyonda gecikme ve fizyolojik kök rezorpsiyonunda gecikme görülmüştür. Uygulanan kemoterapinin süresinin ve neoplazmların tiplerinin oluşan komplikasyonlar üzerinde bir etkisi olmadığı belirlenmiştir. Çocuklarda baş-boyun bölgesi dişında kalan kanserlerin tedavisinde kullanılan antineoplastik ajanların geç dönemde diș ve kök gelișimi üzerinde olumsuz etkileri görülebilir.

Anahtar Kelimeler: diş gelişimi; çene gelişimi; antineoplastik ajan; tümör; çocuk

Abstract: The aim of the present study is to examine the effects of the antineoplastic agents used for the treatment of non-head and neck tumors on the tooth and jaw development in children. This study has been carried out on 30 patients whose ages were between 3 and 14 . The subjects had no systemic conditions and they were receiving chemotherapy for tumors that were localized other than the head and neck region. Periapical and panoramic imaging were done before the treatment, after the treatment and at the end of the 12 months in order to examine the effects of the chemotherapeutic agents on the tooth and jaw development. Delayed eruption, root agenesis, thinning of the roots, delayed apexification and delayed physiologic root resorption were observed in the subjects. The duration of the chemotherapy and the type of neoplasm did not have any effect on the developmental complications. The antineoplastic agents used for the treatment of non-head and neck tumors in children may have negative late effects on the tooth and root development.

Keywords: tooth development; jaw development; antineoplastic agent; tumor; child 


\section{Giriş}

15 yaşın altındaki çocuklarda kazalardan sonra en sik ölüm nedeni malign hastalıklardır. ABD'de yılda 6600 çocuk kanser tanısı almakta ve bunların 5100'ünün yaşayacağ 1 tahmin edilmektedir. Finlandiya'da cocukluk kanserlerinin insidans1 bir milyonda $125^{\prime}$ tir $(1,2)$. Ülkemizde ise her y1l yaklaşık 2400 yeni olgu ortaya çıkmaktadır. En sık lösemi (\%32), lenfoma (\%25.3), beyin tümörleri (\%10.6), Willms's tümörü (\%6.5), nöroblastom (\%6.1), sarkom (\%5.7), kemik tümörleri (\%3), retinoblastom (\%1.3), diğer tümörler (\%9.5) görülür. Pediatrik kanserlerin tedavisi multidisipliner bir yaklaşım gerektirir. Bunlar genel olarak cerrahi, radyoterapi, kemoterapi, laboratuvar yöntemleri ve destek hizmetlerini içermektedir (3-6).

Kanserin medikal tedavisi çocukların bağışıklık sistemini baskılayarak enfeksiyonlara eğilimin artmasına yol açar. Kanser tedavisi sırasında ikincil olarak ortaya çıkan komplikasyonlar ağız boşluğunda sık görülür. Kemoterapinin orodental komplikasyonlarının ileriye dönük olarak incelendiği çok az çalışma olmasına karșıllık bunların çocuklarda daha çok görüldüğü bilinmektedir $(7,8)$. Tedavide kullanılan yöntemler ağız ve çevre dokularda anatomik ve histolojik değişikliklerin ortaya çıkmasına neden olur. Bunlarda mukozal ülserasyonlara, sert doku hasarlarına, gelişimsel bozukluklara, kanamaya, bakteriyel, fungal ve viral kaynaklı enfeksiyonlara, tükürük bezlerinde işlevsel bozukluklara, dental ve periodontal hastalıklara yol açabilirler (9). Tedavi tamamlandiktan sonra bile kaybolmama eğiliminde olan bu lezyonlar, kullanılan ilaçların dozu, kombinasyonu, kullanım süresi ve hastanın bireysel özelliklerine göre farkl1lık gösterirler.

Günümüzün sağllk hizmetlerinin en önemli sorunlarından biri hastanın yaşam kalitesinin idamesi ve bu zorlu dönem boyunca hastaya mümkün olan en iyi bakımın verilmesidir. Erken tanı ve tedavideki çağdaș gelişmeler sayesinde kanserli çocukların \%60'ından çoğu artık tedaviden sonra en ez beş yıl sağ kalmaktadır (10). Uygulanan agresif nitelikteki primer ve adjuvant tedaviler ayr1 ayr1 ya da birlikte kullanılan kemoterapötik ilaçlar ve radyasyonu içerir. $\mathrm{Bu}$ dönemdeki hastaların yaklaşık \%75'i en az bir tip ajanla kemoterapi görmektedir (11). Çocuklarda kemoterapinin ağız komplikasyonları erişkinlere göre 3 kat daha fazladır (12). Bu sorunları saptamak ve gidermek onkolojik tedavi ekibinin bir üyesi olan diş hekimlerinin önemli sorumlulukları arasında yer alır. Antineoplastik tedavi bütün hücreleri etkilediğinden diş minesinde ve kökünde gelişimsel defektlerin oluşması mümkündür. Bunlar kökte kısalma, tamamlanmamış kalsifikasyon, apekslerin erken kapanması, diş gelişiminin durması ya da gecikmesi gibi anomalilerdir (13). Bunlar kanserli çocukların giderek artan sağ kalım süreleri ile bir arada değerlendirildiğinde yaşam kalitesini olumsuz etkileyen sorunlar olarak ortaya çıkarlar.

Kanser tedavisinin oral komplikasyonları genellikle radyoterapi uygulamalarına bağlı olarak incelenir. Benzeri şekilde baş-boyun bölgesi tümörlerinin çalışmalara dahil edilmesi anatomik konumları sebebiyle dişsel gelişim anomalilerinin sinıflandırılmasını güçleștirmektedir. Kemoterapinin diș gelișimi sürecindeki olası etkilerini inceleyen çalışmaların sayısı son derece kısıtlıdır. $\mathrm{Bu}$ yüzden, bu çalışmanın amacı baş ve boyun bölgeleri dişında yerleşim gösteren neoplazmlar sebebiyle sadece kemoterapi tedavisi alan çocuklarda diş gelişimini radyolojik olarak incelemektir.

\section{Gereç ve Yöntem}

$\mathrm{Bu}$ araştırma herhangi bir malign tümör tanısı ile İstanbul Üniversitesi Onkoloji Enstitüsü Pediatrik Onkoloji Bilim Dalına başvuran ve yaşları 3 ile 14 arasında değişen 30 hasta (16 kız 14 erkek) üzerinde yapılmıştır. Hastaların kemoterapi öncesindeki yaş ortalaması 7,24 yıl, kemoterapi tamamlandıktan sonraki yaş ortalamaları 8,43 yıldır. Hastaların ilk başvurularında alınan ananmezlerinde çalışmaya dahil olma koşulları tümör lokalizasyonunun baş boyun bölgesi dişında olması, hastanın sadece kemoterapi tedavisi alacak olması, daha önce radyoterapi almamış 
olma, herhangi bir sistemik hastalı̆̆ın olmaması ve ebeveynler ile çocuğun onay vermesi olarak belirlenmiştir.

Hastalar tanılarına göre 3 ana gruba ayrılmışlardır. 1. grup 9 hastadan oluşan rabdomiyosarkom (RBS) grubu, 2. grup 10 hastadan oluşan Wilms' tümörü ve 3. grup ise diğer tümör tiplerinden oluşmaktadır. $\mathrm{Bu}$ gruptaki hastaların 4 tanesi Ewing sarkomu, 2 tanesi osteosarkom, 3 tanesi Burkitt lenfoması ve 2 tanesi germ hücreli tümör tanıs1 alan olgulardır. Bu hastalarda kemoterapotik ajan olarak etoposid fosfat (Vepesid Er-Kim İlaç Sanayi ve Tic. A.Ş., İstanbul, Türkiye), cisplatin (Cisplatyl, Eczacıbaşı Orna İlaç Tekstil Kimyevi Maddeler San.ve Dış Tic.Ltd.Şti., İstanbul, Türkiye), oncovin (Oncovin, Lilly İlaç Ticaret Ltd.Şti., İstanbul, Türkiye), bleomisin sülfat (Bleocin Onko Koçsel İlaç San. Tic. A.ş,, İstanbul, Türkiye), vincristine sülfat (Vincristine, Atafarm İlaç Sanayi ve Ticaret Ltd.Şti., İstanbul, Türkiye) ve İfosfamid (Holoxan, Eczacıbaş1-Baxter Hastane Ürünleri San. ve Tic. A.ş., İstanbul, Türkiye) maddeleri kullanılmıştır.

Hastalardan tedavi öncesinde, kemoterapi tamamlandiktan hemen sonra ve takip eden 12. ayda İstanbul Üniversitesi Diş Hekimliği Fakültesi Oral Diagnoz ve Radyoloji Anabilim Dalı kliniğinde seri periapikal ve panoramik radyograflar alınmıştır. $\mathrm{Bu}$ radyograflar 3 hekim tarafindan incelenerek ortak kararları nihai yorum olarak kayıt edilmiştir.

Hastaların ayrıntılı anamnezleri alındıktan sonra ağız içi ve ağız dışı muayeneleri yapılmıştır. Ağız içi muayenede mevcut dişlerin durumu değerlendirilmiştir. Dişlerdeki lüksasyonlar, renk değişiklikleri, sürme zamanı gibi kriterler ile bukkal mukoza, dil ve ağız tabanı, sert ve yumuşak damak, dişetleri incelenmiştir. Bu bölgelerde saptanan mukozit, şiddetli gingivitis, herpes simpleks enfeksiyonu, kandidiyazis, lenfadenopati bulguları kaydedilmiştir. Dişlerde ise sürmede gecikme, apeksifikasyonda gecikme, kökte incelme, kök agenezi, çürük indeksinin artışı, fizyolojik kök rezorpsiyonunda gecikme ve mine hipoplazileri değerlendirilmiştir.
Verilerin değerlendirilmesinde Statistical Package for Social Sciences (SPSS) program kullanılmıştır (SPSS Inc. Released 2008. SPSS Statistics for Windows, Version 17.0. Chicago, IL, ABD). Veri setinin özellikleri ortalama, standart sapma, medyan, minimum maximum gibi tanımlayıcı istatistik yöntemleri ile incelenmiştir. Değişkenlerin niteliklerine ve dağılım özelliklerine göre Pearson korelasyonu, kısmi korelasyon, tek yönlü varyans analizi testleri kullanılmıştır.

\section{Bulgular ve Analizler}

Araştırmanın başlangıcında istatistiksel inceleme açısından çalışmanın 75 çocuk hasta üzerinde yapılması öngörülmüştür. Ancak araştırmanın devam ettiği 4 yıllık dönemde gruba dahil edilen 93 hastadan bazıları yeterli veri toplanamadan kaybedilmişler, bir kısmı da ya ailenin çocuğun iyileşmesinden umudu kesmeleri ya da paramedikal tedavileri tercih etmeleri nedeniyle tedavi sürecini bırakmışlardır. İzlem sürecini tamamlayan hasta oran $\% 32,25$ 'tir.

Çalışmaya dahil edilen hastaların diş ve diş kökleri incelenirken normal yapısal etkenler göz önünde bulundurularak sadece normalden sapmalar kayıt altına alınmıştır. Üçüncü büyük azı dişlerinin olmaması toplumda s1k görülen bir durum olduğundan tedaviye bağl1 bir komplikasyon olarak yorumlanmamıştır.

Hasta grubu cinsiyet ayrımı yapılmadan değerlendirildiğinde; 9 hastada sürmede gecikme, 4 hastada kök agenezi, 9 hastada fizyolojik kök rezorpsiyonunda gecikme, 18 hastada mukozitis, 16 hastada gingivitis, 5 hastada kandida enfeksiyonu, 9 hastada herpes simpleks, 2 hastada hipoplazi ve 21 hastada çürük insidansında artış tespit edilmiştir $(p<0,05)$. Çalışma grubunu oluşturan hastaların sadece iki tanesinde tek bir kriter tespit edilmiş diğerlerinde ise birden çok kritere rastlanmıştır. Bu kriterler birden çok dişte olduğu gibi sadece tek bir dişi ilgilendiren lezyonlar da göz önünde bulundurulmuştur.

Hastalara uygulanan toplam kemoterapi dozunun ve süresinin ortalama komplikasyon sayıs1 üzerinde bir etkisi olmadığ 1 belirlenmiştir. Kemoterapiden hemen önce 
alınan radyograflarda herhangi bir bulgu izlenmemiş̧ir. Ancak kemoterapi tamamlandıktan sonra bulgular görülmeye başlamış ve 12. ayda ortalama komplikasyon sayısının artış gösterdiği belirlenmiştir $(\mathrm{p}<0.05)$.

Vincristine dozu ile apeksifikasyondaki gecikme arasında zıt yönlü anlamlı bir ilișki olduğu belirlenmiştir $(p<0,05)$. İfosfamid kullanımı sırasında apeksifikasyonda gecikme ve sürmede gecikme arasında anlamlı bir ilişki olduğu saptanmıştır $\quad(\mathrm{p}<0,05) . \quad$ Vepesid kullanan hastalarda apeksifikasyondaki gecikme artmakta $(\mathrm{p}<0,05)$, fizyolojik kök rezorpsiyonunda gecikme azalmaktadır $(p<0,01)$. Cisplatin kullanımının apeksifikasyondaki gecikme ile ilişkili olduğu bulunmuştur $(\mathrm{p}<0,05)$. Oncovin kullanan hastalarda ise kökte incelme kriterinde artıș görülmüştür $(\mathrm{p}<0,01)$. Bleomisin kullanımı ile fizyolojik kök rezorpsiyonu arasında doğru yönde anlamlı bir ilişki olduğu belirlenmiştir $(\mathrm{p}<0,05)($ Resim 1 ve Resim 2).

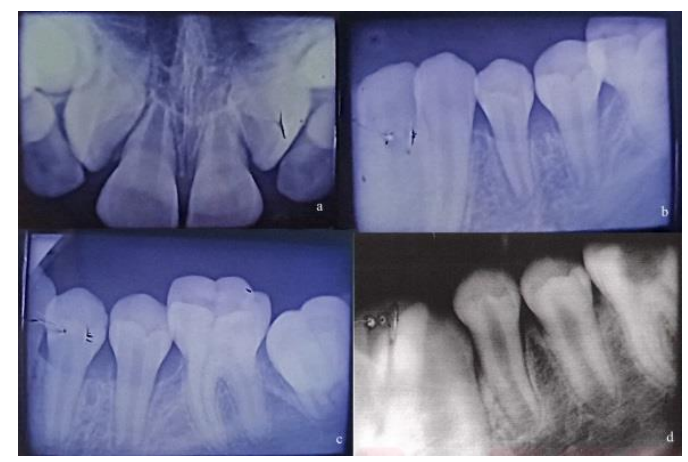

Resim 1. a) Üst keser dişlerde apeksifikasyonda gecikme ve sürmede gecikme görülmektedir b) Alt küçük azılarda apeksifikasyonda gecikme görülmektedir. c) Alt küçük azılarda apeksifikasyonda gecikme ve ikinci büyük azıda sürmede gecikme gözükmektedir. d) Alt küçük azılarda apeksifikasyonda gecikme görülmektedir.

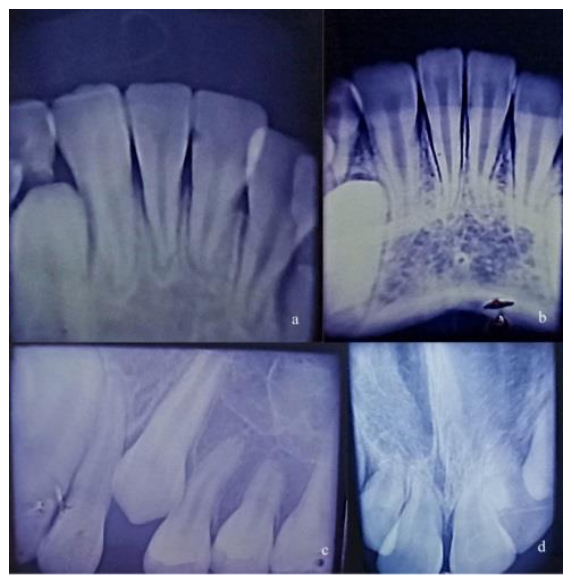

Resim 2. a) Alt kesici dişlerde incelme görülmektedir. b) Alt kesici dişlerde incelme görülmektedir. c) Paralel teknik ile alınan radyografta üst küçük azıda kök agenezi görülmektedir. d) Paralel teknik ile alınan radyografta üst keser dişlerde kök agenezi görülmektedir. 


\section{Tartışma ve Sonuç}

$\mathrm{Bu}$ çalışma baş-boyun bölgesi dışında yerleşim gösteren tümörlerin tedavisinde kullanılan kemoterapi ajanlarının diş gelişimi üzerindeki etkilerini incelemek amaciyla gerçekleştirilmiştir. Çocukluk çağı tümörleri nedeniyle antineoplastik tedavi alan hastaların uzun dönemli incelemeleri sonucunda hem kemoterapinin hem de radyasyon terapisinin sürekli dişlerde, yüzde ve kafatası kemiklerinde gelişim bozuklukluklarına yol açabilecekleri bilinmektedir (13). $\mathrm{Bu}$ bozuklukların derecesi ve şiddeti tedavi alan çocuğun yaşı, tedavi şekli, radyasyon dozu ve uygulandığı alan ile yakından ilgilidir. Hem erişkinlerde hem de çocuklarda kanser tedavisinin ağız yumuşak dokuları üzerindeki olumsuz etkileri bilinmekte olup daha çok radyoterapi uygulaması ile ilişkilendirilmiştir (14). Diğer yandan, baş boyun bölgesi yerleşimli tümörlerin konumları, ağız dokuları üzerindeki doğrudan etkileri ve nüksleri gibi sebeplerden ötürü çalışma gruplarının oluşturulması ve kemoterapinin olası komplikasyonlarının belirlenmesi zordur. $\mathrm{Bu}$ iki etkeni ortadan kaldırılabilmek için bu çalışmaya radyoterapi almayan ve baş boyun bölgesinde tümör oluşumu bulunmayan hastalar dahil edilmiştir.

Kemoterapi alan hastaların \%40'ında ülseratif, hemorajik ya da enfeksiyöz kaynaklı oral komplikasyonlara rastlanabilir. Bunlar hem uygulanan sitotoksik ajanların hızlı bölünen ağı mukozası üzerindeki etkilerinden hem de kemik iliği baskilanmasina sekonder olarak ortaya çıkmaktadır (15). Bu tür ajanların terapötik ve stomatotoksik etkileri arasındaki güvenlik marjini çok dar olduğundan ağız komplikasyonları kaçınılmazdır. Yumuşak dokular açısından değerlendirildiğinde Dreizen ve ark. (16) kemoterapi alan 1500 lösemi hastasının 704 tanesinde dudak, dil, dişeti, oral enfeksiyonlar, mukozit ve hemoraji bulguları olduğunu bildirmişlerdir. Aynı araştırmacılar hemorajileri incelediklerinde ise 1093 hastanın 163 tanesinde en çok trombositopeni ile ilişkilendirilen kanamalar olduğunu belirtmişlerdir (17). Bizim çalışmamızda izlenen yumuşak doku komplikasyonlarının nitelikleri benzer olmakla beraber hemoraji tablosuna rastlanmamıștır. Diğer yandan, alt çenedeki skuamöz hücreli karsinom sebebiyle kombine antineoplastik tedavi alan hastaları inceleyen Fuchihata ve ark. (18) üç yıllık takip süresince sadece mukozit olgularına rastadıklarını bildirmişlerdir. Bizim bulgularımızla farklılık gösteren bu durum uygulanan kemoterapötik ajanlara, doz ve süreye bağlı olarak ortaya çıkmış olabilir.

Tedavide kullanılan ajanların çok çeşitli olması nedeniyle bunların diş ve çene gelişimi üzerindeki etkilerini incelemek oldukça güçtür. Jaffe ve ark. (19) sadece kemoterapi alan 23 hastanın 5 tanesinde diş ve kök anomalileri bulunduğunu bildirmişlerdir. Ancak bu araştırmacılar diş ve kök anomalilerini bir arada değerlendirdiklerinden iki çalışmanın doğrudan karşılaştırılması olası değildir. Dahlof ve ark. (20) kemoterapi sonrasında dişlerin hem mine hem de dentin tabakalarında histolojik bozukluklar olabileceğini ilk ortaya koyan araştırmacılardandır. Yan kesici dişlerin mine tabakasında ve küçük azı dişlerinin hem mine hem de dentin tabakalarındaki çizgilenmede artış olduğunu bildiren çalışmacılar bunları kemoterapötik ajanların kullanımı ile ilişkilendirmişlerdir. Kaste ve ark. (21) RBM tedavisi alan çocuk hastalarda kemoterapinin ve radyoterapinin dişler üzerindeki etkilerini incelemişlerdir. Kemoterapötik ajanlar bu çalışmada kullanılanlarla uyumlu olmasına karş1lık, kök büyümesinde durma, mikrodonti ve hipodonti bulguları bu çalışma ile uyumlu değildir. $\mathrm{Bu}$ durum kemoterapi ve radyoterapiyi aynı anda alan çocuklarda diş ile ilgili komplikasyonların farklilik gösterebileceğini vurgulamaktadır. Rosenberg ve ark. (22) akut lenfositer lösemi nedeniyle kemoterapi alan 17 çocukta yaptıkları subjektif değerlendirme sonucunda azı dişlerinin ve kanin dişinin köklerinde kısalmalar ve apikal bölgede incelmeler tespit etmişlerdir. Bizim çalışmamıza lösemili hastalar dahil edilmemiş olmakla beraber farklı tanı alan hastalarda uygulanan ayn kemoterapi ajanlarının yol açtığ komplikasyonlar benzerlik göstermektedir. Diğer yandan Dens ve ark. (23) bu çalışma ile benzer tanılar almış hasta gruplarını incelediklerinde plak indeksi ve immunglobulin A miktarları arasında anlamlı 
bir ilişki bulmuştur. Ancak bu araștırmacılar çürük sıklığında bir artış olmadığını bildirmiş̧lerdir. $\mathrm{Bu}$ çalışma ile belirgin bir farkl1l1k içeren bu durum iki hasta grubunun ağı diş sağlığı ve beslenme alışkanlıkları arasındaki farklılıklardan ileri gelmiş olabilir. 20 yıldan bu yana yapılan çalışmalar arasında halen sadece kemoterapiye odaklanan çalışmaların sayısı sınırlıdır. Bunları inceleyen Busenhart ve ark. (24) renkleşme, diş gelişiminde gecikme, hipoplazi, mikrodonti ve erken apeksifikasyonun kemoterapi sonrası arttığı konusunda düşük değerde ancak anlamlı kanıtlar bulunduğunu bildirmişlerdir. $\mathrm{Bu}$ durum ise Nishimura ve ark.'nın (25) bildirdiği gibi remisyon için gerekli olan ilaç konsantrasyonlarının odontoblast ve ameloblastlar üzerindeki olumsuz etkileri ile açıklanabilir. Bizim çalışmamızın bulguları da kemoterapi ajanlarının diş gelişimi üzerindeki olumsuz etkilerinin olduğunu ve izlenen komplikasyonların uygulanan tedavi protokolüne göre farklılık gösterebileceğini ortaya koymuştur.

$\mathrm{Bu}$ çalışmanın bulguları değerlendirilirken göz önünde bulundurulması gereken bazı

\section{KAYNAKLAR}

1. Fayle SA, Curzon ME. Oral complications in pediatric oncology patients. Pediatr Dent. 1991;13:289-95.

2. Simon AR, Roberts MW. Management of oral complications associated with cancer therapy in pediatric patients. ASDC $J$ Dent Child. 1991;58:384-9.

3. Krywulak ML. Dental considerations for the pediatric oncology patient. J Can Dent Assoc. 1992;58(2):125-30.

4. Naylor GD, Terezhalmy GT. Oral complications of cancer chemotherapy: prevention and management. Spec Care Dentist. 1988;8:150-6.

5. Pajari U, Lanning M, Larmas M. Prevalence and location of enamel opacities in children after antineoplastic therapy. Community Dent Oral Epidemiol. 1988;16:222-6.

6. Cevik N. 9. Pediatrik tümörler ve tıpta yenilikler kongre raporu, Türkiye çocukluk kanser vakaları. Ankara (özet kitabı); 1996.

7. Ritwik P, Chrisentery-Singleton TE. Oral and dental considerations in pediatric cancers. Cancer Metastasis Rev. 2020;39:43-53.

8. Almendra Mattos RM, de Mendonca RMH, Dos Santos Aguiar S. Adherence to dental treatment reduces oral complications related to cancer kısitlılıklar vardır. Tek merkezli olması, tedavi protokollerinin çeşitliliği, deneklerin arasındaki yaş dönemi farklılıkları, bazı tümörlerin yeterli örneklem genişliğine ulaşabilmek için bir arada değerlendirmek zorunda kalınması ve görüntüleme yöntemlerinin sınırlılıkları bunların en önemli olanlarıdır. Ayrıca, denek sayısının yetersizliği bu tür çalışmalarda sık ortaya çıkan bir sorundur. $\mathrm{Bu}$ araştırmada da başlangıçta planlanan örneklem genişliğinin sadece \%32,25'ine ulaşılabilmiş olması dikkate alınması gereken bir durumdur.

\section{Sonuç}

Çocuk hastalarda baş ve boyun bölgesi dışında yerleşim gösteren neoplazmların tedavisinde kullanılan kemoterapi ajanları, diş dokularında 12 . aydan sonra radyografik olarak belirgin hale gelen yapisal değişikliklere yol açabilir. Ajanların nitelikleri ortaya çıkan komplikasyonun tipi üzerinde etkilidir. Ancak, toplam doz ve uygulama süresinin komplikasyon sayısı üzerinde bir etkisi bulunmamaktadır.

treatment in pediatric and adolescent patients. Support Care Cancer. 2020;28:661-70.

9. Farsi DJ. Children Undergoing Chemotherapy: Is It Too Late for Dental Rehabilitation? J Clin Pediatr Dent. 2016;40:503-5.

10. Gatta G, Botta L, Rossi S, Aareleid T, BielskaLasota M, Clavel J, et al. Childhood cancer survival in Europe 1999-2007: results of EUROCARE-5--a population-based study. Lancet Oncol. 2014;15:35-47.

11. Erginel B, Vural S, Akin M, Karadag CA, Sever $\mathrm{N}$, Yildiz A, et al. Wilms' tumor: a 24-year retrospective study from a single center. Pediatr Hematol Oncol. 2014;31:409-14.

12. King E. Oral sequelae and rehabilitation considerations for survivors of childhood cancer. Br Dent J. 2019;226:323-9.

13. Wani V, Kulkarni A, Pustake B, Takate V, Wani P, Sondhi JS. Prevalence, complications and dental management of the oral cancer in the pediatric patients. $J$ Cancer Res Ther. 2018;14:1407-11.

14. Velten DB, Zandonade E, Monteiro de Barros Miotto MH. Prevalence of oral manifestations in children and adolescents with cancer submitted to chemotherapy. BMC Oral Health. 2017;17:49. 
15. Berger Velten D, Zandonade E, Monteiro de Barros Miotto MH. Prevalence of oral manifestations in children and adolescents with cancer submitted to chemotherapy. BMC Oral Health. 2016;16:107.

16. Dreizen S, McCredie KB, Keating MJ, Bodey GP. Oral infections associated with chemotherapy in adults with acute leukemia. Postgrad Med. 1982;71(6):133-46.

17. Dreizen S, McCredie KB, Keating MJ. Chemotherapy-associated oral hemorrhages in adults with acute leukemia. Oral Surg Oral Med Oral Pathol. 1984;57:494-8.

18. Fuchihata H, Furukawa S, Murakami S, Kubo K, Shimizutani K, Ikeda $\mathrm{H}$, et al. Results of combined external irradiation and chemotherapy of bleomycin or peplomycin for squamous cell carcinomas of the lower gingiva. Int $J$ Radiat Oncol Biol Phys. 1994;29:705-9.

19. Jaffe N, Toth BB, Hoar RE, Ried HL, Sullivan MP, McNeese MD. Dental and maxillofacial abnormalities in long-term survivors of childhood cancer: effects of treatment with chemotherapy and radiation to the head and neck. Pediatrics. 1984;73:816-23.

20. Dahllof G, Rozell B, Forsberg CM, Borgstrom B. Histologic changes in dental morphology induced by high dose chemotherapy and total body irradiation. Oral Surg Oral Med Oral Pathol. 1994;77:56-60.

21. Kaste SC, Hopkins KP, Bowman LC. Dental abnormalities in long-term survivors of head and neck rhabdomyosarcoma. Med Pediatr Oncol. 1995;25:96-101.

22. Rosenberg SW. Oral care of chemotherapy patients. Dent Clin North Am. 1990;34:239-50.

23. Dens F, Boute P, Vinckier F, Declerck D. Quantitative determination of immunologic components of salivary gland secretion in longterm, event-free pediatric oncology patients. Oral Surg Oral Med Oral Pathol Oral Radiol Endod. 1995;79:701-4.

24. Busenhart DM, Erb J, Rigakos G, Eliades T, Papageorgiou SN. Adverse effects of chemotherapy on the teeth and surrounding tissues of children with cancer: A systematic review with meta-analysis. Oral Oncol. 2018;83:64-72.

25. Nishimura S, Inada H, Sawa Y, Ishikawa H. Risk factors to cause tooth formation anomalies in chemotherapy of paediatric cancers. Eur J Cancer Care (Engl). 2013;22:353-60. 